\title{
PENULISAN KARANGAN NARASI BERDASARKAN PENGALAMAN PRIBADI SISWA
}

\author{
Musyawir \& Siti Hajar Loilatu Program \\ Pos-el: musvawir.rs@gmail.com
}

(Diterima: 03 Agustus; Direvisi 04 Agustus; Disetujui: Agustus 2020)

\begin{abstract}
This study aims to describe the ability of class X MA Uswatun Hasanah Lala students in writing narrative essays based on personal experience. This research was designed using quantitative description methods. The variable observed in this study was the ability of students to write narrative essays based on personal experience in class X students of Uswatun Hasanah. Thus, the type of variable is a single variable. Data collection techniques in this study in the form of tests and observations. Furthermore, the data analysis technique in this study uses statistical techniques. The results showed that of the 29 research subjects who scored 66 or above as many as 12 students or $41.31 \%$ and research subjects who scored less than 66 were 17 students or 58.62\%. Based on the mastery criteria that the research subject was declared successful if $85 \%$ of students had a value of

66 and above, it can be concluded that the class X MA Uswatun Hasanah Lala was able to write narrative essays based on personal experience.
\end{abstract}

Keywords: Writing narrative essay, personal experience

\begin{abstract}
Abstrak
Penelitian ini bertujuan mendeskripsikan kemampuan siswa kelas X MA Uswatun Hasanah Lala dalam menulis karangan narasi berdasarkan pengalaman pribadi. Penelitian ini dirancang dengan menggunakan metode deskripsi kuantitatif. Variabel yang diamati dalam penelitian ini adalah kemampuan siswa dalam menulis karangan narasi berdasarkan pengalaman pribadi pada siswa kelas X Uswatun Hasanah. Dengan demikian, jenis variabelnya adalah variable tunggal. Teknik pengumpulan data dalam penelitian ini berupa tes dan observasi. Selanjutnya, teknik analisis data dalam penelitian ini dengan menggunakan teknik statistik. Hasil penelitian menunjukan bahwa dari 29 subjek penelitian yang memperoleh nilai 66 ke atas sebanyak 12 siswa atau $41.31 \%$ dan subjek penelitian yang memperoleh nilai kurang dari 66 sebanyak 17 siswa atau 58.62\%. Dengan berdasarkan pada kriteria penguasaan bahwa subjek penelitian dinyatakan berhasil apabila $85 \%$ siswa meperoleh nilai 66 ke atas, maka dapat di simpulkan bahwa siswa kelas X MA Uswatun Hasanah Lala mampu menulis karangan narasi berdasarkan pengalaman pribadi.
\end{abstract}

Kata kunci: Menulis karangan narasi, pengalaman pribadi 


\section{PENDAHULUAN}

Bahasa merupakan sarana komunikasi berupa lisan maupun tulisan yang menghubungkan antara manusia satu dengan lainnya. Melalui bahasa, setiap manusia dapat mengungkapkan pikirannya sehingga orang lain dapat mengetahui apa yang dipikirkan. Ada empat keterampilan berbahasa yang perlu diperhatikan, yakni ketrampilan menyimak, keterampilan berbicara, ketrampilan membaca, dan keterampilan menulis (Tarigan, 2000:1)

Keempat keterampilan tersebut merupakan keterampilan yang dipelajari di sekolah, baik sekolah dasar maupun sekolah menengah ke atas. Pembelajaran bahasa di sekolah pada umumnya bertujuan untuk meningkatkan keempat keterampilan berbahasa tersebut. Seiring dengan perkembangan zaman, bahasa akan selalu mengalami perubahan. Oleh sebab itu, dibutuhkan berbagai teknik, metode, dan strategi yang tepat di dalam pembelajaran bahasa.

Menulis merupakan salah satu dari empat keterampilan berbahasa yang dipelajari di sekolah. Keterampilan menulis merupakan keterampilan untuk mengungkapkan ide, gagasan, dan buah pikiran siswa dalam bentuk tulisan. Oleh karena itu, menulis merupakan keterampilan yang bersifat produktif, yakni menghasilkan karya yang merupakan buah pemikiran. Mengungkapkan apa yang dipikirkan ke dalam bentuk tulisan itu tidak mudah. Hal itu disebabkan menulis merupakan keterampilan yang menuntut sejumlah kemampuan dan persyaratan.

Tulisan tidak hanya harus runtut dan mudah dipahami oleh pembaca, tetapi juga harus sesuai dengan kaidah kebahasaan yang baik dan benar. Oleh karena itu, latihan yang tekun diperlukan untuk menghasilkan tulisan yang baik.

Penguasaan keterampilan menulis di sekolah sangat penting. Bagaimanapun juga, melalui keterampilan menulis siswa dapat melatih diri sendiri untuk mengolah pikirannya dan dituangkan ke dalam bentuk tulisan. Menulis bukan hanya sekadar pengetahuan, tetapi juga merupakan suatu keterampilan yang harus dipelajari dengan penggunaan berbagai strategi, metode, dan media pembelajaran yang tepat, sehingga keterampilan menulis di sekolah hasilnya optimal.

Mengingat pentingnya keterampilan menulis dalam kegiatan pembelajaran, siswa perlu dibina dan diberi latihan secara tekun untuk memperoleh hasil yang optimal. Sesuai dengan Kurikulum tiga belas (K13), salah satu tujuan standar kompetensi kelas X siswa MA adalah mengungkapkan pikiran dan pengalaman dalam buku harian dan surat pribadi. Pada penelitian ini difokuskan pada keterampilan menulis pengalaman pribadi.

Pengalaman pribadi merupakan sebuah pengalaman yang dapat dialami setiap orang dalam hidupnya. Pengalaman yang terjadi pada seseorang bisa sedih, senang, bahkan mengesankan. Pembelajaran menulis karangan narasi di sekolah bertujuan untuk meningkatkan kemampuan siswa dalam menuangkan ide atau gagasan yang berupa cerita pengalaman yang masih terkenang di dalam ingatan ke dalam bentuk tulisan. Selain itu, siswa dapat saling berbagi pengalaman yang mengesankan dengan teman lain. Menulis pengalaman pribadi adalah bagian dari narasi. Narasi adalah cerita.

Berdasarkan hasil observasi peneliti di MA Uswatun Hasanah, dapat disimpulkan bahwa pembelajaran keterampilan menulis karangan narasi berdasarkan pengalaman pribadi masih rendah. Hal itu disampaikan oleh guru Bahasa Indonesia MA Uswatun Hasanah pada saat wawancara dengan peneliti. Menurut beliau, nilai rata-rata siswanya masih rendah dalam keterampilan menulis, khususnya menulis pengalaman pribadi pada siswa kelas X MA Uswatun 
Hasanah. Kelas X merupakan kelas yang rata-ratanya masih rendah dalam keterampilan menulis. Hal itu dibuktikan dengan nilai rata-rata siswa pada pembelajaran menulis pengalaman pribadi hanya sebesar 64,25 , sedangkan ketuntasan minimal sebesar 66. Berdasarkan hal tersebut, maka kelas X MA Uswatun Hasanah memerlukan adanya pembelajaran khusus dalam menulis karangan narasi.

Permasalahan yang ditemukan peneliti, yaitu siswa masih belum bisa menemukan ide sendiri untuk menulis karangan narasi. Siswa juga kurang mampu untuk mengembangkan ide (gagasan ) dan mengorganisasikannya dengan baik. Faktor lain yang menyebabkan kurang optimalnya pembelajaran menulis di MA Uswatun Hasanah, yakni kurang minatnya siswa dalam pembelajaran menulis.

Siswa menganggap kalau menulis adalah pekerjaan yang membutuhkan tenaga dan pikiran yang banyak karena keterampilan menulis membutuhkan konsentrasi dan keseriusan yang tinggi. Hal itu yang membuat siswa menjadi malas untuk berlatih menulis. Selain hal-hal tersebut, hal yang paling sering dilakukan siswa pada saat menulis, yaitu kurang memperhatikan penggunaan tata bahasa yang baik dan benar karena siswa cenderung lebih mementingkan panjang pendeknya karangan, bukan kualitas karangan.

Pembelajaran menulis karangan narasi di MA Uswatun Hasanah masih rendah juga disebabkan belum digunakannya metode dan media pembelajaran yang tepat. Pembelajaran menulis pengalaman pribadi hanya menggunakan metode ceramah tanpa adanya variasi metode dan media pembelajaran lainnya. Variasi penggunaan teknik, metode, ataupun media dalam pembelajaran dapat membuat siswa lebih semangat dan antusias dalam mengikuti pembelajaran.

Berdasarkan fenomena tersebut, perlu diadakan suatu pembelajaran khusus mengenai keterampilan menulis karangan narasi pada siswa kelas MA Uswatun Hasanah. Upaya yang dapat dilakukan untuk meningkatkan pembelajaran keterampilan

menulis karangan narasi, yaitu dengan mengenalkan siswa dengan metode dan media pembelajaran yang bervariasi dan menyenangkan salah satunya dengan berdasarkan pengalaman dari masing-masing siswa.

Selanjutnya, rumusan masalah dalam penelitian ini adalah bagaimanakah peningkatan kemampuan menulis karangan narasi pada siswa kelas X MA Uswatun Hasanah berdasarkan pengalaman pribadi? Adapun tujuan penelitian ini adalah Adapun tujuan penelitian penulisan dalam penelitian ini adalah untuk mengembangkan kemampuan menulis karangan narasi berdasarkan pengalaman pribadi siswa $\mathrm{X}$ MA Uswatun Hasanah.

\section{TINJAUAN PUSTAKA}

\section{Pengertian Menulis}

Hargrove dan Pottet dalam Abdurrahman (2001:239) mengemukakan bahwa menulis merupakan penggambaran visual tentang pikiran, perasaan, dan ide dengan menggunakan simbol-simbol sistem bahasa penulisannya untuk keperluan komunikasi atau mencatat. Tarigan (2001:21) mendefinisikan menulis adalah lambang-lambang grafis dari bahasa yang dipahami oleh penulisnya maupun orangorang lain yang menggunakan bahasa yang sama dengan penulis tersebut.

Menurut Djago Tarigan dalam Elina Syarif, Zulkarnaini, Sumarno (2009:5) menulis berarti mengekpresikan secara tertulis gagasan, ide, pendapat, atau pikiran dan perasaan. Lado dalam Elina Syarif, Zulkarnaini, Sumarno (2009:5) juga mengungkapkan pendapatnya mengenai menulis yaitu: meletakkan simbol grafis yang mewakili bahasa yang dimengerti orang lain.

M. Atar Semi (2007:14) dalam bukunya mengungkapkan pengertian menulis adalah suatu proses kreatif memindahkan gagasan ke dalam lambanglambang tulisan. Burhan Nurgiantoro (1988: 273) menyatakan bahwa menulis adalsh 
aktivitas aktif produktif, yaitu aktivitas menghasilkan bahasa.

Berdasarkan pendapat tersebut, dapat disimpulkan bahwa menulis merupakan suatu kegiatan untuk menciptakan suatu catatan atau informasi pada suatu media dengan menggunakan aksara. Menulis biasa dilakukan pada kertas dengan menggunakan alat-alat seperti pena atau pensil. Namun dengan semakin berkembangnya teknologi seperti saat ini, menulis juga bisa dilakukan dengan menggunakan komputer atau laptop

\section{Tujuan Menulis}

\section{Tujuan} menulis

adalah memroyeksikan sesuatu mengenai diri seseorang. Setiap penulis harus mengungkapkan dengan jelas tujuan penulisan yang akan dikerjakannya. Perumusan tujuan penulisan sangat penting dan harus ditentukan terlebih dahulu karena hal ini merupakan titik tolak dalam seluruh kegiatan menulis. Rumusan tujuan penulisan adalah suatu gambaran penulis dalam kegiatan menulis selanjutnya. Dengan menentukan tujuan penulisan, akan diketahui apa yang harus dilakukan pada tahap penulisan.

\section{Teori Menulis}

\section{Menurut}

Tompkins

(1994:10), mengemukakan lima tahap menulis yang harus dilakukan, dengan pentahapanpentahapan sebagai berikut:

1. Pra menulis (Prewriting): siswa memilih topik, siswa mengumpulkan dan menyesuaikan ide-ide, siswa mengidentifikasi pembacaannya, siswa mengidentifikasi tujuan penulis, siswa memlih bentuk yang sesua berdasarkan pembaca dan tujuan menulis dengan aktifitas pengarang persiapan menulis cerita, menggambar, membaca, memikirkan tulisan, menyusun gagasan dan mengembangkan rencana.

2.Pengedrafan (Drafting): siswa menulis draf kasar, siswa menulis pokok-pokok yang menarik pembaca, siswa lebih menekankan isi dari pada mekanik dengan aktifitas pengarang merangkaikan gagasan dalam sebuah tulisan tanpa memperhatikan kerapain atau mekanik.

3.Merevisi (Revising): siswa membagi tulisannya kepada kelompok, siswa mendiskusikan tulisannya kepada teman, siswa membuat perbaikan sesuai komentar teman dan guru.

4.Mengedit (Editing): siswa membaca ulang tulisan, siswa membantu membaca ulang tulisan temannya, siswa mengidentifikasi kesalahan mekanisme dan memperbaiki.

5.Mempublikasikan (Publishing): siswa mempublikasikan tulisan dalam bentuk yang sesuai, siswa membagi tulisan yang sudah selesai kepada temannya.

\section{Pengertian Karangan}

Karangan adalah bentuk tulisan yang mengungkapkan pikiran dan perasaan pengarang dalam satu kesatuan tema yang utuh. Karangan diartikan pula dengan rangkaian hasil pikiran atau ungkapan perasaan ke dalam bentuk tulisan yang teratur. Karangan yang terdiri dari beberapa paragraf, masing-masing dari paragraf tersebut berisi pikiran utama dan diikuti oleh pikiran-pikiran penjelas. Sebuah paragraf belum tentu dapat terwujud keselurahan karangan. Namun, sebuah paragraf sudah bisa memberikan suatu informasi kepada pembaca karena ada kalanya suatu karangan hanya berisi satu paragraf saja sehingga dalam karangan tersebut hanya berisi satu pikiran pokok.

Pada umumnya, karangan dipandang sebagai suatu perbuatan atau kegiatan komunikatif antara penulis dan pembaca berdasarkan teks yang telah dihasilkan (Ahmadi, 1988: 20). Begitu juga istilah karangan (komposisi) yang dikemukakan Ahmadi (1990: 1) bahwa karangan diartikan sebagai rangkaian kata-kata atau kalimat. Selain itu, karangan menurut Gie (1995: 17) memiliki pengertian karangan adalah hasil perwujudan gagasan seseorang dalam bahasa tulis yang dapat dibaca dan dimengerti oleh pembaca.

\section{Langkah-langkah Menulis Karangan}

Adapun langkah-langkah mengarang 
menurut Setiawan Djuharie (2001: 57), meliputi di bawah ini.

1.Menentukan atau memilih tema atau topik karangan

Langkah paling awal dalam membuat suatu karangan adalah menentukan tema atau topik karangan. Tema diartikan pokok pikiran, sedangkan topik adalah pokok pembicaraan. Apabila dilihat dari sudut sebuah karangan yang telah selesai tema adalah suatu amanat utama yang disampaikan oleh penulis melalui karangannya. Dalam kenyataannya untuk menulis suautu karangan, penulis harus memilih suatu topik atau pokok pembicaraan. Dengan demikian, pada waktu menyusun sebuah tema untuk untuk sebuah karangan ada dua unsur yang paling dasar yaitu topik atau pokok pembicaraan dan tujuan yang hendak dicapai melalui topik tersebut.

\section{Menetapkan Tujuan}

Setiap kegiatan yang dilakukan tentu memiliki tujuan. Demikian halnya dengan mengarang/menulis. Menetapkan tujuan tulisan adalah penting sebelum menulis. Karena tujuan sangat berpengaruh dalam menetapkan bentuk, panjang, sifat dan cara penyajian tulisan. Tujuan tulisan harus jelas suatu tulisan yang tidak dilandasi dengan tujuan yang jelas dan mungkin hanya mewujudkan tulisan yang buruk atau tidak dapat dipahami oleh pembaca. Jadi penetapan tujuan itu sangat membantu penulis dalam mengembangkan tulisannya dan dapat memberikan arah kepada penulis. Dengan menetapkan tujuan yang jelas akan membantu penulis memperoleh gambaran tentang persoalan yang akan ditulisnya dan membangkitkan semangat penulis untuk merangkaikan kata-kata yang lebih jelas dan terarah.

\section{Mengumpulkan Informasi/bahan}

Untuk mencapai tujuan yang telah ditetapkan, perlu mencari bahan berupa keteranganketerangan yang berhubungan dengan topik tersebut. Kegiatan mengumpulkan bahan dapat dilakukan dengan cara observasi atau mengadakan pengamatan terhadap satu proses atau keinginan sesuatu yang diperlukan dan akan dijadikan sumber penulisan.

4. Membuat Kerangka Tulisan

Kerangka tulisan adalah garis besar cerita yang akan dituangkan pada sebuah tulisan. Sebelum menulis, seorang penulis perlu menetapkan kerangka tulisan. Kerangka tulisan merupakan pedoman atau acuan penulis tentang hal-hal apa saja yang akan ditulis, sehingga dengan menggunakan kerangka tulisan alur cerita yang akan ditulis semakin jelas dan terarah. Jarang seseorang dalam menuangkan isi pikirannya sekaligus secara teratur terperinci dan sempurna tanpa sebuah kerangka tulisan. Hal ini sesuai dengan pendapat Gorys Keraf (1994:132) bahwa; Kerangka karangan adalah rencana kerja yang memuat garis-garis besar dari suatu karangan yang akan digarap."

5. Mengembangkan Kerangka Karangan

Setelah kerangka karangan disusun, maka tahap selanjutnya adalah mengembangkannya menjadi sebuah tulisan yang utuh. Pengembangan kerangka karangan dilakukan satu persatu. Dalam penulisan atau pengembangan kerangka karangan ada beberapa unsur yang harus diperhatikan dan unsur-unsur tersebut merupakan penilaian baik tidaknya hasil karangan yang dibuat. Unsur-unsur tersebut adalah isi gagasan yang dikemukakan, organisasi isi (urutan peristiwa), tata bahasa, pilihan struktur dan kosakata serta penggunaan ejaan yang tepat.

\section{Karangan Narasi}

Istilah narasi atau sering juga disebut naratif berasal dari kata bahasa Inggris narration (cerita) dan narrative (yang menceritakan). Karangan yang disebut narasi menyajikan serangkaian peristiwa. Karangan ini berusaha menyampaikan serangkaian kejadian menurut urutan terjadinya (kronologis), dengan maksud memberi arti kepada sebuah atau serentetan kejadian, 
sehingga pembaca dapat memetik hikmah dari cerita itu (Suparno dan Yunus, 2009:4.31). Keraf (2010:136) membatasi pengertian narasi sebagai suatu bentuk wacana yang sasaran utamanya adalah tindak tanduk yang dijalin serta dirangkaikan menjadi sebuah peristiwa yang terjadi dalam satu kesatuan waktu. Struktur narasi dapat dilihat dari komponen-komponen yang membentuknya: perbuatan, penokohan, latar, dan sudut pandang. Tetapi dapat juga dianalisa berdasarkan alur (plot) narasi (Keraf, 2010:145).

Umumnya, orang mengakui bahwa tujuan menulis narasi secara fundamental ada dua, yaitu (1) hendak memberikan informasi atau wawasan dan memperluas pengetahuan pembaca, dan (2) hendak memberikan pengalaman estetis kepada pembaca. Tujuan pertama menghasilkan jenis narasi yang lazim disebut narasi informasional atau narasi ekspositoris, sedangkan tujuan hendak memberikan pengalaman estetis menghasilkan jenis narasi yang lazim disebut narasi artistik atau narasi sugestif.

\section{Pengalaman Pribadi}

Tulisan pribadi adalah suatu pernyataan dari gagasan-gagasan serta perasaan-perasaan kita mengenai pengalaman-pengalaman kita sendiri yang ditulis, baik bagi kesenangan kita sendiri ataupun bagi kepentingan dan kenikmatan sanak saudara. Tulisan pribadi adalah suatu bentuk tulisan yang memberikan sesuatu yang paling menyenangkan dalam penjelajahan diri pribadi sang penulis. Hanya catatan atau laporan pribadilah yang dapat menangkap kembali atau merekam secara tepat apa-apa yang telah kita rasakan atau alami pada masa lalu.

Tulisan membuat kita sadar akan kehidupan, sebab manakala kita menaruh pikiran-pikiran kita mengenai kehidupan ke dalam kata-kata, maka kita menjadi lebih sadar akan kehidupan itu sendiri. Tulisan pribadi juga merupakan terapeutik atau "ilmu pemeriksaan dan pengobatan" suatu alat untuk menganalisis diri yang mengizinkan kita memahami diri kita lebih baik (Tarigan, 2001:30).
Pengalaman adalah hal-hal yang pernah dialami, dijalani, dan ditanggung oleh setiap orang. Setiap orang pasti mempunyai pengalaman yang mengesankan. Pengalaman yang mengesankan adalah pengalaman yang membekas di hati dan pengalaman tersebut sulit dihapus dari ingatan (Sapari, 2008:18). Jenis pengalaman ada enam, yaitu pengalaman lucu, pengalaman aneh, pengalaman mendebarkan, pengalaman mengharukan, pengalaman memalukan, dan pengalaman menyakitkan.

\section{Aspek-aspek yang dinilai dalam menulis \\ Pengalaman Pribadi}

Menulis merupakan kegiatan yang menghasilkan sebuah tulisan. Tulisan hasil karya tersebut tidak lepas dari kegiatan penyuntingan jika ingin benar-benar tulisan yang dihasilkan baik. Oleh karena itu, dalam menulis ada beberapa aspek yang perlu diperhatikan agar tulisan yang dihasilkan memenuhi kriteria tulisan yang baik. Unsurunsur karangan yang baik mengandung tiga bagian utama, yaitu (1) pendahuluan, pada bagian ini menjelaskan secara singkat ide pokok atau tema karangan, (2) isi, pada bagian isi sebagai jembatan yang menghubungkan bagian pendahuluan dan penutup dan merupakan penjelasan terperinci terhadap apa yang diutarakan pada bagian pendahuluan, (3) penutup, pada bagian penutup adalah salah satu kombinasi dari fungsi untuk memberikan simpulan, penekanan bagianbagian tertentu, klimaks, melengkapi, dan merangsang pembaca untuk mengerjakan sesuatu tentang apa yang sudah diceritakan (Tarigan, 2009:1).

\section{Kriteria Penilaian Menulis 8. Karangan Narasi Berdasarkan Pengalaman Pribadi}

Memberikan penilaian terhadap hasil karangan tidaklah mudah,karena setiap peserta didik memiliki pemikiran yang berbeda-beda dalam memilih gagasan untuk di tuankan mereka kedalam bentuk tulisan.Burhan Nurgiantoro (2009:304) mengemukkan "penilaian terhadap hasil karangan bebas mempunyai kelemahan 
pokok, yaitu rendahnya kadar objektivitas. Bagaimana juga betapapun kadarnya, unsur subjektivitas penilaian pasti berpengaruh",

Selain model tersebut, Harris (dalam

Burhan Nurgantoro, 2009:306) mengemukkan model pendekatan analisis yang lain, misalnya analisis unsur-unsur karangan. Unsur-unsur dimaksud adalah "content (isi gagasan yang di kemukakakan),form (organisasi isi), grammer (tata bahasa dan pola kalimat), style (gaya:pilihan struktur dan kosa kata),dan mechanics (ejaan).',

\section{METODE PENELITIAN}

\section{Jenis Penelitian}

Penelitian ini termasuk penelitian deskripstif kuantitatif. Jenis peneltian deskriptif kuatitatif merupakan jenis penelitian melalui pengukuran dan analisis matematika. Hasil pengolahan disajikan sebagai temuan peneltian ini.

\section{Variabel Penelitian}

Variabel yang diamati dalam penelitian ini adalah kemampuan siswa dalam menulis karangan narasi berdasarkan pengalaman pribadi pada siswa kelas $\mathrm{X}$ Uswatun Hasanah Lala. Dengan demikian, dapat diaphami bahwa jenis variabel dalam peneltian ini adalah variabel tunggal.

\section{Definisi Operasional Variabel}

Untuk memudahkan pemahaman tentang penelitian yang dilakukan. Maka perlu dikemukakan defenisi operasional variabel penelitian yang dimaksud sebagai berikut:

1. Menulis merupakan suatu kegiatan untuk menciptakan suatu catatan atau informasi pada suatu media dengan menggunakan aksara.

2. Karangan adalah bentuk tulisan yang mengungkapkan pikiran dan perasaan pengarang dalam satu kesatuan tema yang utuh.

Kemampuan menulis berarti kemhiran siswa yang ditunjukan dengan skor.

4. Narasi adalah karangan yang isinya berupa cerita tentang suatu rangkaian peristiwa yang terjadi dalam satu kesatuan waktu.

5. Keterampilan menulis narasi merupakan 10 kemampuan siswa dalam membuat karangan narasi yang meliputi proses penulisan dan hasil tulisan narasi.

\section{Populasi dan Sampel}

Populasi dalam penelitian ini adalah keseluruhan siswa kelas X MA Uswatun Hasanah Lala Kabupaten Buru tahun ajaran 2017/2018, jumlah populasinya sebanyak 29 siswa. Berdasarkan jumlah siswa tersebut, maka sampel penelitian ini berjumlah 29 siswa, karena jumlah populasi kurang dari 100 siswa.

\section{Instrumen Penelitian}

Instrumen penelitian adalah suatu alat yang digunakan untuk mengukur fenomena alam maupun sosial yang diamati (Sugiono, 2006 : 148). Sehubungan dengan itu, untuk mengukur kemampuann siswa kelas X MA Uswatun Hasanah perlu dipersiapkan instrument penelitian. Instrumen penelitian yang digunakan dalam penelitian ini berupa tes tertulis yaitu kemampuan menulis karangan narasi siswa kelas $\mathrm{X}$ MA Uswatun Hasanah.

\section{Teknik Pengumpulan Data}

Teknik yang digunakan untuk mengumpulkan data dalam penelitian ini adalah tes tertulis, yaitu siswa ditugasi untuk dapat menentukan sendiri ide pokok dari sebuah karangan narasi. Pengumpulan data ini dilaksanakan pada kelas kontrol dan kelas eksperimen.

Untuk dapat mengumpulkan data dalam penelitian ini maka, diadakan pengumpulan data yang meliputi:

1. Observasi adalah untuk mengetahui jumlah dan keadaan siswa yang akan diteliti secara menyeluruh.

Tes adalah suatu proses untuk dapat mengetahui kemampuan siswa dalam mengikuti pembelajaran. 


\section{Teknik Analisis Data}

Data yang terkumpul dianalisis dengan menggunakan teknik statistik deskriptif. Dengan menggunakan langkah-langkah menganalisis data sebagai berikut:

1. Membuat daftar skor mentah

2. Membuat distribusi frekuensi dan skor mentah

3. Mengklasifikasi kemampuan siswa sesuai dengan acuan yang ditentukan.

\section{PEMBAHASAN}

\section{Hasil Penelitian}

Penyajian hasil analisis data nilai mentah siswa kelas $\mathrm{X}$ MA Uswatun Hasanah Lala sebagaimana tampak pada paparan berikut ini.

\section{Data Statistik Deskriptif Hasil}

Kemampuan Menulis Karangan

Narasi Berdasarkan Pengalaman

Pribadi Pada Siswa Kelas X MA

Uswatun Hasanah Lala

a. Analisis Data Skor Mentah

Sesuai dengan hasil analisis data yang diolah diperoleh gambaran hasil tes siswa kelas $X$ MA Uswatun Hasanah Lala seperti yang dinyatakan dalam tabel 1 di bawah ini.

Tabel 1. Skor Perolehan Nilai Mentah Kemampuan Menulis Karangan Narasi Berdasarkan Pengalaman Pribadi Pada Siswa Kelas X MA Uswatun Hasanah Lala

\begin{tabular}{|c|c|c|}
\hline No & Kode siswa & $\begin{array}{c}\text { Skor } \\
\text { perolehan }\end{array}$ \\
\hline 1 & 001 & 80 \\
\hline 2 & 002 & 90 \\
\hline 3 & 003 & 60 \\
\hline 4 & 004 & 80 \\
\hline 5 & 005 & 80 \\
\hline 6 & 006 & 90 \\
\hline 7 & 007 & 70 \\
\hline 8 & 008 & 70 \\
\hline 9 & 009 & 60 \\
\hline 10 & 010 & 70 \\
\hline 11 & 011 & 60 \\
\hline 12 & 012 & 70 \\
\hline 13 & 013 & 60 \\
\hline 14 & 014 & 60 \\
\hline
\end{tabular}

\begin{tabular}{|c|c|c|}
\hline 15 & 015 & 70 \\
\hline 16 & 016 & 60 \\
\hline 17 & 017 & 60 \\
\hline 18 & 018 & 60 \\
\hline 19 & 019 & 60 \\
\hline 20 & 020 & 90 \\
\hline 21 & 021 & 60 \\
\hline 22 & 022 & 60 \\
\hline 23 & 023 & 70 \\
\hline 24 & 024 & 60 \\
\hline 25 & 025 & 60 \\
\hline 26 & 026 & 60 \\
\hline 27 & 027 & 60 \\
\hline 28 & 028 & 60 \\
\hline 29 & 029 & 60 \\
\hline Jumlah & 29 Siswa & 2010 \\
\hline
\end{tabular}

Berdasarkan tabel tersebut menunjukkan bahwa sampel penelitian berjumlah 29. Skor tertinggi adalah 90 dan skor terendah adalah 60. Sampel penelitian 001 memperoleh skor 90, sampel penelitian 002 memperoleh skor 90 , sampel penelitian 003 memperoleh skor 90, sampel penelitian 004 memperoleh skor 80, sampel penelitian 005 memperoleh skor 80, sampel penelitian 006 memperoleh skor 80, sampel penelitian 007 memperoleh skor 70, sampel penelitian 008 memperoleh skor 70, sampel penelitian 009 memperoleh skor 70, sampel penelitian 010 memperoleh skor 70, sampel penelitian 011 memperoleh skor 70, sampel penelitian 012 memperoleh skor 70, sampel penelitian 013 memperoleh skor 60, sampel penelitian 014 memperoleh skor 60, sampel penelitian 015 memperoleh skor 60, sampel penelitian 016 memperoleh skor 60, sampel penelitian 017 memperoleh skor 60, sampel penelitian 018 memperoleh skor 60, sampel penelitian 019 memperoleh skor 60, sampel penelitian 020 memperoleh skor 60, sampel penelitian 021 memperoleh skor 60, sampel penelitian 022 memperoleh skor 60, sampel penelitian 023 memperoleh skor 60, sampel penelitian 024 memperoleh skor 60, sampel penelitian 025 memperoleh skor 60, sampel penelitian 
027 memperoleh skor 60, sampel penelitian 028 memperoleh skor 60, sampel penelitian 029 memperoleh skor 60.

Berdasarkan hasil tes perolehan skor mentah siswa, maka dapat distribusikan ke bentuk frekuensi dan persentase sebagaimana tertera pada tabel 2 berikut ini. Tabel 2. Distribusi Frekuensi dan Persentase Hasil Tes Siswa

\begin{tabular}{|c|c|c|c|}
\hline No. & Nilai & $\begin{array}{c}\text { Frekue } \\
\text { nsi }\end{array}$ & $\begin{array}{c}\text { Persentase } \\
(\%)\end{array}$ \\
\hline 1 & 90 & 3 & 10.34 \\
\hline 2 & 80 & 3 & 10.34 \\
\hline 3 & 70 & 6 & 20.68 \\
\hline 4 & 60 & 17 & 58.62 \\
\hline \multicolumn{2}{|c|}{ Jumlah } & 29 & $100 \%$ \\
\hline
\end{tabular}

Berdasarkan tabel 2 tersebut diperoleh gambaran tentang frekuensi dan hasil tes siswa sebagai berikut: nilai tertinggi 90 diperoleh oleh 3 siswa (10.34\%); nilai 80 diperoleh oleh 3 siswa (10.34\%); dan nilai 70 diperoleh oleh 6 siswa $(20.68 \%)$; nilai 60 diperoleh oleh 17 siswa (58.62).

Berdasarkan data distribusi frekuensi dan presentase nilai siswa subjek penelitian ditransfer ke dalam konversi angka berskala 10-100. Untuk lebih jelasnya, dapat diperhatikan pada tabel 3 berikut ini.

Tabel 3. Distribusi Frekuensi dan Persentase

Skor Tes Hasil Belajar Menulis

Karangan Narasi Berdasarkan Pengalaman Pribadi

\begin{tabular}{|c|c|c|c|}
\hline No. & $\begin{array}{c}\text { Rentang } \\
\text { Skor }\end{array}$ & Frekuensi & $\begin{array}{c}\text { Persentase } \\
(\%)\end{array}$ \\
\hline 1 & 100 & 0 & 0 \\
\hline 2 & 90 & 3 & 10.34 \\
\hline 3 & 80 & 3 & 10.34 \\
\hline 4 & 70 & 6 & 20.68 \\
\hline 5 & 60 & 17 & 58.62 \\
\hline 6 & 50 & 0 & 0 \\
\hline
\end{tabular}

\begin{tabular}{|c|c|c|c|}
\hline 7 & 40 & 0 & 0 \\
\hline 8 & 30 & 0 & 0 \\
\hline 9 & 20 & 0 & 0 \\
\hline 10 & 10 & 0 & 0 \\
\hline \multicolumn{2}{|c|}{ Jumlah } & 29 siswa & $100 \%$ \\
\hline
\end{tabular}

Berdasarkan tabel 3 di atas diperoleh gambaran bahwa nilai diperoleh sampel penelitian sangat bervariasi. Tidak ada sampel penelitian yang memperoleh nilai 100 , 90. Siswa yang memperoleh nilai 90 berjumlah 3 orang $(10.34 \%)$, siswa yang memperoleh nilai 80 berjumlah 3 orang $(10.34 \%)$, siswa yang memperoleh nilai 70 berjumlah 6 orang (20.68\%), siswa yang memperoleh nilai 60 berjumlah 17 orang (58.62). dan tidak satu siswa pun yang memperoleh nilai 50, 40, 30, 20, dan 10 .

Berdasarkan distribusi frekuensi dan persentase skor tes hasil belajar menulis karangan narasi berdasarkan pengalaman pribadi dapat diketahui kategori kemampuan siswa. Untuk lebih jelasna, dapat dilihat tabel 4 berikut ini.

Tabel 4. Kategorisasi Tes Tingkat Kemampuan, Frekuensi dan Persentase Siswa

\begin{tabular}{|c|c|c|c|c|}
\hline No & $\begin{array}{c}\text { Interval } \\
\text { Nilai }\end{array}$ & $\begin{array}{c}\text { Tingkat } \\
\text { Kemampuan }\end{array}$ & $\begin{array}{c}\text { Freku } \\
\text { ensi }\end{array}$ & $\begin{array}{c}\text { Perse } \\
\text { ntase } \\
(\%)\end{array}$ \\
\hline $\begin{array}{l}1 . \\
2 . \\
3 . \\
4 . \\
5 .\end{array}$ & $\begin{array}{c}85-100 \\
75-84 \\
60-74 \\
40-59 \\
0-39\end{array}$ & $\begin{array}{c}\text { Sangat } \\
\text { tinggi } \\
\text { Tinggi } \\
\text { Sedang } \\
\text { Rendah } \\
\text { Sangat } \\
\text { rendah }\end{array}$ & $\begin{array}{c}3 \\
3 \\
23 \\
0 \\
0\end{array}$ & $\begin{array}{c}10.34 \\
10.34 \\
79.01 \\
0 \\
0\end{array}$ \\
\hline \multicolumn{3}{|c|}{ Jumlah } & $\begin{array}{c}29 \\
\text { siswa }\end{array}$ & $100 \%$ \\
\hline
\end{tabular}

Berdasarkan tabel kategorisasi tes tingkat kemampuan, frekuensi dan persentase siswa sampel menunjukka bahwa 
siswa yang berada pada kategori tinggi diperoleh 3 siswa (10.34\%), siswa yang berada pada kategori sedang diperoleh 23 siswa $(80.01 \%)$, dan tidak ada siswa yang berada pada kategori rendah dan kategori sangat rendah. Berdasarkan tabel di atas maka hasil belajar siswa pada kegiatan tes berada pada kategori rendah.

Hasil analisis statistik deskriptif yang berkaitan dengan nilai tes siswa sampel di atas dapat dilihat pada tabel 5 berikut ini.

Tabel 5. Deskripsi Nilai Hasil Tes Siswa

\begin{tabular}{|c|c|}
\hline Statistik & \multicolumn{2}{|c|}{ Nilai } \\
& Statistik \\
\hline Sampel penelitian & 29 \\
Nilai tertinggi & 90 \\
Nilai terendah & 60 \\
Nilai tengah & 70 \\
Nilai ideal & 100 \\
Rata-rata & 69.31 \\
& \\
& \\
\hline
\end{tabular}

Berdasarkan tabel 5, dapat digambarkan bahwa dari 29 siswa yang dijadikan sampel penelitian untuk pembelajaran menulis karangan narasi berdasarkan gambar, pada umumnya memiliki tingkat hasil belajar siswa yang cenderung sedang.

Berdasarkan nilai statistik hasil belajar menulis karangan narasi berdasarkan pengalaman pribadi dapat diketahui tingkat kemampuan siswa. Untuk lebih jelasnya dapat dilihat tabel 6 berikut ini.

Tabel 6. Klasifikasi Tingkat Kemampuan Tes Hasil Belajar Menulis Karangan Narasi Berdasarkan Pengalaman Pribadi

\begin{tabular}{|l|l|c|c|}
\hline No. & $\begin{array}{l}\text { Perolehan } \\
\text { Nilai }\end{array}$ & Frekuensi & $\begin{array}{c}\text { Persentas } \\
\text { e }(\%)\end{array}$ \\
\hline 1 & $\begin{array}{l}\text { Nilai 66 } \\
\text { ke atas }\end{array}$ & 12 & 41.37 \\
\hline
\end{tabular}

\begin{tabular}{|l|c|c|c|}
\hline 2 & $\begin{array}{l}\text { Di bawah } \\
66\end{array}$ & 17 & 58.62 \\
\hline & Jumlah & 29 siswa & $100 \%$ \\
\hline
\end{tabular}

Berdasarkan tabel 6 di atas diketahui bahwa hasil tes siswa sampel yang memperoleh nilai $66 \mathrm{ke}$ atas berjumlah 12 siswa $(41.38 \%)$ dan sampel yang memperoleh nilai di bawah 66 berjumlah 17 siswa (58.62\%). Hal ini membuktikan bahwa nilai yang diperoleh siswa sampel sebesar 66 ke atas tidak mencapai kriteria tingkat kemampuan siswa.

Berdasarkan hasil kemampuan tes hasil belajar menulis karangan narasi berdasarkan pengalaman pribadi pada siswa kelas X MA Uswatun Hasanah Lala, peneliti dapat menyimpulkan bahwa siswa belum mampu menulis karangan narasi berdasarkan pengalaman pribadi.

\section{Pembahasan}

Berdasarkan hasil analisis data, maka dapat dikemukakan bahwa temuan yang diperoleh dalam penelitian ini tentang kemampuan menulis karangan narasi berdasarkan pengalaman pribadi pada siswa kelas X MA Uswatun Hasanah Lala, Hasil penelitian ini menunjukkan bahwa kemampuan siswa, tentang menulis karangan narasi berdasarkan pengalaman pribadi, dikategorikan sedang.

Berdasarkan hasil tes pada 29 siswa pada kelas $\mathrm{X}$ yang dijadikan sampel penelitian dalam menulis karangan narasi berdasarkan pengalaman pribadi,diketahui bahwa perolehan nilai secara klasikal sebanyak 20.10 dengan nilai rata-rata 69.31. Sedangkan perolehan skor sangat tertinggi yang diperoleh siswa adalah 90 yang diperoleh 3 orang (10.34\%). Selanjutnya, sampel yang memperoleh skor 80 berjumlah

3 orang $(10.34 \%)$, sampel yang memperoleh skor 70 berjumlah 6 orang $(20.68 \%)$, dan sampel yang memperoleh skor 60 berjumlah 
Hasil penelitian ini menunjukkan bahwa kemampuan siswa kelas $\mathrm{X}$, tentang kemampuan menulis karangan narasi berdasarkan pengalaman pribadi dikategorikan sedang. Hal ini dinyatakan karena perolehan nilai siswa masih sedang. Dari 29 sampel yang diberi tes atau diteliti, yang memperoleh nilai 66 ke atas sebanyak 12 siswa atau $41.38 \%$ sedangkan sampel yang memperoleh nilai 66 ke bawah sebanyak 17 siswa atau 58.62\%. Kategorisasi nilai sedang tersebut tentu saja sudah berhasil dalam kemampuan nilai siswa secara klasikal.

Berdasarkan uraian tersebut tampak bahwa kemampuan siswa kelas $\mathrm{X}$ sebagai sampel tentang kemampuan menulis karangan narasi berdasarkan pengalaman pribadi berada pada kategori sedang karena dari 29 sampel yang diberi tes, sampel penelitian yang memperoleh nilai dengan kategori sedang berjumlah 23 siswa atau $79.01 \%$ lebih sangat tinggi dari sampel penelitian yang memperoleh nilai tinggi sebanyak 3 siswa atau $10.34 \%$, Hal ini merupakan salah satu indikator bahwa pembelajaran menulis karangan narasi berdasarkan pengalaman pribadi pada siswa kelas X MA Uswatun Hasanah Lala sudah berhasil walaupun secara klasikal sedang tetapi belum mencapai nilai ketuntasan minimal yaitu 66 .

\section{PENUTUP}

Berdasarkan uraian pada bab terdahulu, maka kesimpulan yang diperoleh berdasarkan hasil penelitian dan analisis data yang telah dilakukan adalah sebagai berikut:

Siswa sampel berjumlah 29 orang. Skor maksimal yaitu 100. Skor tertinggi yang diperoleh siswa sampel yaitu 90, dan skor terendah yang diperoleh sampel penelitian yaitu 60, skor tengah yang diperoleh sampel penelitian yaitu 70 , dan jumlah nilai secara menyeluruh yaitu 20.10 dengan nilai rata-rata sampel penelitian secara klasikal yaitu 69.31.
Kemampuan menulis karangan narasi berdasarkan pengalaman pribadi pada siswa kelas X MA Uswatun Hasanah Lala sedang belum berhasil dengan baik. Hal ini berdasar pada hasil analisis data yaitu sampel penelitian yang memperoleh nilai $66 \mathrm{ke}$ atas sebanyak 12 siswa atau $41.38 \%$ dan sampel penelitian yang memperoleh nilai di bawah 66 sebanyak 17 siswa atau 58.62\%.

Dengan demikian kemampuan menulis karangan narasi berdasarkan pengalaman pribadi pada siswa kelas X MA Uswatun Hasanah Lala, secara klasikal sudah berhasil dengan baik karena sampel penelitian sedang secara klasikal belum mencapai nilai diatas KKM yaitu 66.

Bertolak dari hasil kesimpulan tentang kemampuan menulis karangan narasi berdasarkan pengalaman pribadi pada siswa kelas X MA Uswatun Hasanah Lala, maka saran yang dapat dikemukakan dalam penelitian ini adalah

1.Disarankan kepada siswa untuk terus aktif dalam kegiatan pembelajaran yang disajikan oleh guru.

2.Pihak sekolah terus aktif berupaya untuk meningkatkan kualitas dan hasil belajar siswa dengan meningktatkan mutu pendidikan.

3.Diharapkan guru sebagai pendidik senantiasa berusaha mencari alternatif terbaik dalam menyampaikan pembelajaran.

4.Untuk meningkatkan kemampuan menulis karangan narasi berdasarkan pengalaman pribadi pada siswa kelas X MA Usawatun Hasanah Lala, guru mata pelajaran bahasa Indonesia di sekolah tersebut hendaknya mengakrabkan siswa dengan pendekatan menulis dengan baik dalam bentuk proses maupun praktikum.

5.Guru hendaknya banyak memberikan kesempatan kepada siswa untuk menulis karangan narasi berdasarkan pengalaman pribadi. 


\section{DAFTAR PUSTAKA}

Badu, Tri K., and Muh S. Ikbal. "Perbedaan Pemahaman Konsep Fisika Siswa Melalui Model Problem-based Learning Dan Pembelajaran Interaktif: (Differences in Students' Understanding of Physics Concepts Through the Problem-based Learning Model and Concept-based Interactive Learning)." Uniqbu Journal of Exact Sciences, vol. 1, no. 2, 2020, pp. 23-30, doi:10.47323/ujes.v1i2.27.

Badu, Tri K., and Muh S. Ikbal. "Perbedaan Pemahaman Konsep Fisika Siswa Melalui Model Problem-based Learning Dan Pembelajaran Interaktif: (Differences in Students' Understanding of Physics Concepts Through the Problem-based Learning Model and Concept-based Interactive Learning)." Uniqbu Journal of Exact Sciences, vol. 1, no. 2, 2020, pp. 23-30, doi:10.47323/ujes.v1i2.27.

Bennett, R., \& Bennett, S. T. (1991). free activities you can do with your child. Holbrook, MA: Bob Adams

Bin Tahir, S. Z. (2015). Multilingual behavior of Pesantren IMMIM students in Makassar. Asian EFL Journal, 86, 4564.

Bin Tahir, S. Z. (2015). The attitude of Santri and Ustadz toward multilingual education at Pesantren. International Journal of Language and Linguistics, 3(4), 210-216.

Bin-Tahir, S. Z., Atmowardoyo, H., Dollah, S., \& Rinantanti, Y. (2017). Multilingual Instructional Model of Pesantren Schools in Indonesia. Journal of Language Teaching and Research, 8(6), 1210-1216. Byrne, Donn. 1987. Teaching Oral English.

Bin-Tahir, S. Z., Hanapi Hanapi, I. H., \& Suriaman, A. (2020). Avoiding Maluku Local Languages Death Through Embedded Multilingual Learning Model: Menghindari Kematian Bahasa
Daerah Maluku melalui Model Pembelajaran Embedded Multilingual. Uniqbu Journal of Social Sciences, 1(1), 53-60.

Bin-Tahir, S. Z., Hanapi Hanapi, I. H., \& Suriaman, A. (2020). Avoiding Maluku Local Languages Death Through Embedded Multilingual Learning Model: Menghindari Kematian Bahasa Daerah Maluku melalui Model Pembelajaran Embedded Multilingual. Uniqbu Journal of Social Sciences, 1(1), 53-60.

Bin-Tahir, S. Z., Saidah, U., Mufidah, N., \& Bugis, R. (2018). The impact of translanguaging approach on teaching Arabic reading in a multilingual classroom. Ijaz Arabi Journal of Arabic Learning, 1(1).

Bin-Tahir, S. Z., Amri, M., Nagauleng, A. M., Diniaty, A., \& Hajar, I. The Social Media Use For Digital Natives: Parenting Model Of Muslim Cleric Families.

Bin-Tahir, S. Z., Amri, M., Nagauleng, A. M., Diniaty, A., \& Hajar, I. The Social Media Use For Digital Natives: Parenting Model Of Muslim Cleric Families.

Hajar, I., Rahman, A., Tenriawali, A. Y., \& Mangesa, R. (2020). THE INFLUENCE OF PODCASTS IN LEARNING ENGLISH VOCABULARY OF TWELVE GRADE STUDENTS OF SMA NEGERI 2 BURU. EXPOSURE: JURNAL PENDIDIKAN BAHASA INGGRIS, 9(2), 235-249.

Hajar, I., Salija, K., \& Muliati, A. (2019). THE INTERFERENCE OF INDONESIAN ON THE STUDENTS'ENGLISH WRITING OF MUHAMMADIYAH UNIVERSITY OF MAKASSAR (Doctoral dissertation, Doctoral dissertation, 
(UJSS) Vol. 1, No 2, Agustus 2020: 1-12

UNIVERSITAS

NEGERI

MAKASSAR).

Hajar, I., Ternate, K., Mukadar, S., Nirwana, A. R., \& Badu, T. K. (2020). Learning Style Of An Outstanding Student In English Learning At SMA Negeri 1 Buru:(Gaya Belajar Bahasa Inggris Siswa Berprestasi di SMA Negeri 1 Buru). Uniqbu Journal of Social Sciences, 1(2), 78-85.

Iye, R., Tenriawali, A. Y., Susiati, A., \& Buton, D. (2020). Makna dan Fungsi Emosi Mahasiswa Kota Baubau dalam Ranah Demonstrasi: The Meaning And Emotional Function Of Students Of Baubau City In The Demonstration Plan. Uniqbu Journal of Social Sciences, 1(1), 25-37.

Loilatu, S. H., Rusdi, M., \& Musyowir, M. (2020). Penerapan Sistem Informasi Manajemen Pendidikan dalam Proses Pembelajaran. Jurnal Basicedu, 4(4), 1408-1422.

Malmia, Wa, et al. "Efektifitas Pembelajaran Contextual Teaching and Learning (Ctl) Terhadap Hasil Belajar Matematika Siswa : (the Effectiveness of Contextual Teaching and Learning (Ctl) on Student Mathematics Learning Achievements)." Uniqbu Journal of Exact Sciences, vol. 1, no. 2, 2020, pp. 31-39, doi:10.47323/ujes.v1i2.26.

Mukadar, S., \& Budiono, B. (2020). Analisis Pemerataan Pendidikan Tingkat Pendidikan Dasar Di Kabupaten Buru Provinsi Maluku. Jurnal Kebijakan dan Pengembangan Pendidikan, 7(2).

Nirwana, A. R., \& Nirwana, A. R. (2018). Effects of Writing Corrective Feedback onStudents' Linguistic Error (Doctoral dissertation, Doctoral dissertation, UNIVERSITAS NEGERI MAKASSAR).

Publisher

Rahman, A., \& Hajar, I. (2020). The Effect of Audiobook on Reading Comprehension of the Eleventh Grade Students of SMA Negeri 2 Buru. ELT WORLDWIDE, 7(2), 104-115.
Rahman, A., \& Hajar, I. (2020). The Effect of Audiobook on Reading Comprehension of the Eleventh Grade Students of SMA Negeri 2 Buru. ELT WORLDWIDE, 7(2), 104-115.

Sumiaty, S., Kaharuddin, K., Tenriawali, A. Y., \& Hajar, I. (2020). PENGUNGKAPAN CIRI PRIBADI MELALUI GAYA BAHASA PADA NOVEL HEKSALOGI SUPERNOVA KARYA DEWI LESTARI: KAJIAN STILISTIKA: (Disclosure of Personal Characters through Language Styles in Dewi Lestari's Supernova Hexalogy Novel: Stilistics Study). Uniqbu Journal of Social Sciences, 1(3), 113-123. https://doi.org/10.47323/ujss.v1i3.72

.Saidah, U., Bin-Tahir, S. Z., \& Mufidah, N. (2018). ARABIC TEACHERS'COMPETENCE: A CASE OF MADRASAH SCHOOLS IN MALUKU. Ijaz Arabi Journal of Arabic Learning, 1(2).

Sam, B., Iye, R., Ohoibor, M., Umanailo, M. C. B., Rusdi, M., Rahman, A. B. D., \& Hajar, I. (2019). Female Feminism in the Customary Island of Buru. Int. J. Sci. Technol. Res, 8(8), 1877-1880.

Singapore. Longman

Singapore

Sitompul, Hamela S., et al. "Penerapan Model Pembelajaran Sinektikuntuk Meningkatkan Hasil Belajar Peserta Didik Pada Pokok Bahasan Kologatif Larutan : (Application of Synectic Learning Models to Improve Students' Learning Achievement in Solution Colligative Discussion)." Uniqbu Journal of Exact Sciences, vol. 1, no. 2, 2020, pp. 52-58, doi:10.47323/ujes.v1i2.45

Sumiaty, S., Kaharuddin, K., Tenriawali, A. Y., \& Hajar, I. (2020). PENGUNGKAPAN CIRI PRIBADI MELALUI GAYA BAHASA PADA NOVEL HEKSALOGI SUPERNOVA KARYA DEWI LESTARI: KAJIAN STILISTIKA: (Disclosure of Personal 
(UJSS) Vol. 1, No 2, Agustus 2020: 1-12

Characters through Language Styles in Dewi Lestari's Supernova Hexalogy Novel: Stilistics Study). Uniqbu Journal of Social Sciences, 1(3), 113123.

https://doi.org/10.47323/ujss.v1i3.72

Susiati, S., Masniati, A., Tuasalamony, K., Hatuwe, R. S. M., Tahir, S. Z. B., Tenriawali, A. Y., \& Marasabessy, R. N. (2020). MEMBANGUN KETAHANAN RELEGIUS ANAK MELALUI ACTIVE PARENTAL INVOLVEMENT. Jurnal Islam Nusantara, 4(1), 111-125.

Tenriawali, A. Y. (2018). Representasi korban kekerasan dalam teks berita daring tribun timur: analisis wacana kritis [the representation victims of violence in tribun timur online news text: critical discourse analysis]. TOTOBUANG, 6 (1), 1, 15.

Tuharea, V. U., Bin Tahir, S. Z., Ami, I. S. O., \& Rahman, A. (2020). Buru Language Conservation Through Sustainable Mulok Learning In Buru Regency:(Konservasi Bahasa Buru melalui Pembelajaran Mulok Berkelanjutan di Kabupaten Buru). Uniqbu Journal of Social Sciences, 1(2), 49-55.

Twister+4108+308+article.htm.

Wael, A., Tinggapy, H., Rumata, A. R., Tenriawali, A. Y., Hajar, I., \& Umanailo, M. C. B. (2021). REPRESENTASI PENDIDIKAN KARAKTER DALAM DAKWAH ISLAM DI MEDIA SOSIAL. Academy of Education Journal, 12(1), 98-113. https://doi.org/10.47200/aoej.v12i1.428

Yusdianti, A. (2020). THE REPRESENTATION VICTIMS OF VIOLENCE IN TRIBUN TIMUR ONLINE NEWS TEXT: CRITICAL DISCOURSE ANALYSIS.

Wael, A., Tinggapy, H., Rumata, A. R., Tenriawali, A. Y., Hajar, I., \& Umanailo, M. C. B. (2021). REPRESENTASI PENDIDIKAN KARAKTER DALAM DAKWAH ISLAM DI MEDIA SOSIAL. Academy of Education Journal, 12(1), 98-113. https://doi.org/10.47200/aoej.v12i1.428

Yusuf, S., Umanailo, M. C. B., \& Nirwana, A. R. (2020). RELASI KEPALA DESA DAN BADAN PERWAKILAN DESA DALAM PEMANFAATAN DANA DESA DI KECAMATAN NAMLEA. Sosioglobal: Jurnal Pemikiran dan Penelitian Sosiologi, 4(2), 130-140. 